\title{
Az angiotenzinkonvertálóenzim-gén I/D polimorfizmusának hatása a vesetranszplantált betegek cardiovascularis rizikójára és a grafttúlélésre
}

\author{
Fedor Roland dr. ${ }^{1}$. Kovács Dávid Ágoston dr. ${ }^{1}$ - †Lőcsey Lajos dr. ${ }^{1}$ \\ Fagyas Miklós dr. ${ }^{2}$ - Asztalos László dr. ${ }^{1}$ - Tóth Attila dr. ${ }^{2}$ \\ Debreceni Egyetem, Általános Orvostudományi Kar, 'Sebészeti Intézet, \\ Szervtranszplantációs Nem Önálló Tanszék, ${ }^{2}$ Kardiológiai Klinika, Klinikai Fiziológiai Tanszék, Debrecen
}

\begin{abstract}
Bevezetés: A végstádiumú vesebetegségben szenvedők kezelésében a veseátültetés hosszabb túlélést biztosít, mint a vesepótló kezelések egyéb formái. A recipiens várható túlélését leginkább a magasabb szív-ér rendszeri eredetủ halálozás befolyásolja. A transzplantált vese károsodásának leggyakoribb oka az idült allograft-nephropathia. Célkitúzés: A szerzők a recipiens és a beültetett vese hosszú távú túlélésével egyértelmú összefüggést mutató biomarkerek azonosítását tüzték ki célul. Módszer: A retrospektív vizsgálatba 72 beteget vontak be. Meghatározták az angiotenzinkonvertálóenzim-gén I/D polimorfizmusát, az enzim aktivitását, a vesefunkciót, valamint a szív morfológiai jellemzőit. Eredmények: $\mathrm{Az}$ angiotenzinkonvertálóenzim-gén $\mathrm{DD}$ genotípusa egyaránt összefüggést mutatott az idült allograft-nephropathia és a súlyos fokú bal kamrai hypertrophia elófordulásával. A vesefunkció és a szívizom-hypertrophia mértéke között szoros összefüggést találtak. Köpetkeztetések: Eredményeik szerint az angiotenzinkonvertálóenzim-gén I/D polimorfizmus ismerete lehetőséget ad a recipiens és a transzplantált vese túlélésének becslésére, a veszélyeztetett betegek azonosítására. Ezeknek a betegeknek a körében szükségesnek túnik a renin-angiotenzin rendszert gátló gyógyszerek alkalmazása, együttmúködésük fenntartása a gyógyszerszedés vonatkozásában. Orv. Hetil., 2016, 157(24), 938-845.
\end{abstract}

Kulcsszavak: vesetranszplantáció, angiotenzinkonvertáló enzim, I/D polimorfizmus, idült allograft-nephropathia, balkamra-hypertrophia

The effect of the I/D polymorphism of the angiotensin-converting enzyme gene on the cardiovascular risk and graft survival of kidney transplant patients

Introduction: Renal transplantation provides longer life expectancy in patients with renal failure. Nonetheless, this improved life expectancy is still shorter than that for the general population. The main couse of death in renal transplant patients is cardiovascular disease, and chronic allograft nephropathy is the most significant cause of graft loss. Genetic polymorphisms of the renin angiotensin system have been implicated in both chronic allograft nephropathy and fatal cardiovascular diseases. Aim: The long term goal of the authors was to improve the survival of renal transplanted patients. The authors aimed to identify novel biomarkers which correlate with the survival of the transplant organ and the recipient with a special attention to elements of the renin-angiotensin system. Method: A retrospective clinical trial was performed involving 72 renal transplanted patients. Angiotensin-converting enzyme I/D genotypes and activity, kidney function and morphological properties of the heart were determined. Results: A significant positive correlation was found between the DD genotype of the angiotensin-converting enzíme gene, and the DD genotype predicted severe left ventricular hypertrophy. Conclusions: These findings suggest that the I/D genotypes of the angiotensin-converting enzyme gene predict not only the expected survival of the transplanted organ, but also that of the patient. Patients with the DD genotype are more susceptible for transplant failure. These patients should be identified and a special attention should be made on their pharmacological treatment (renin-angiotensin system inhibition), and their complience should also be maintained. 
Keywords: kidney transplantation, angiotensin-converting enzyme, I/D polymorphism, chronic allograft nephropathy, left ventricular hypertrophy

Fedor, R., Kovács, D. Á. +Löcsey, L., Fagyas, M., Asztalos, L., Tóth, A. [The effect of the I/D polymorphism of the angiotensin-converting enzyme gene on the cardiovascular risk and graft survival of kidney transplant patients]. Orv. Hetil., 2016, 157(24), 938-945.

(Beérkezett: 2016. április 10.; elfogadva: 2016. április 21.)

\begin{abstract}
Rövidítések
ACE = angiotenzinkonvertáló enzim; ACEI = ACE-inhibitor; Ang-I = angiotenzin-I; Ang-II = angiotenzin-II; AR = (acute rejection) heveny kilökődés; $\mathrm{ARB}=$ angiotenzin-II-receptorantagonista (blokkoló); ATlR = l-es típusú angiotenzin-II-receptor; AT2R = 2-es típusú angiotenzin-II-receptor; BMI = (body mass index) testtömegindex; BSA = (body surface area $)$ testfelszín; CAN = krónikus allograft-nephropathia; $\mathrm{CIT}=$ (cold ischemic time) hideg ischaemiás idő; $\mathrm{CNI}=$ calcineurininhibitor; DGF $=$ (delayed graft function) későn induló graftfunkció; DNS = dezoxiribonukleinsav; ESRD = (end-stage renal disease) végstádiumú vesebetegség; HLA = humán leukocyta-antigén; IF/TA = interstitialis fibrosis/tubulus atrophia; $\mathrm{LVH}=$ (left ventricular hypertrophy) bal kamrai hypertrophia; LVMI = (left ventricular mass index $)$ bal kamrai izomtömeg indexe; NRF = normal renal function; $\mathrm{PCR}=$ polimeráz láncreakció; PRA = panel reaktív antitest titer; RAS = reninangiotenzin rendszer; RAAS $=$ renin-angiotenzin-aldoszteron rendszer; RNS = ribonukleinsav; $\mathrm{Tx}=$ transzplantáció; $\mathrm{UH}=$ ultrahang
\end{abstract}

A végstádiumú vesebetegség (ESRD) incidenciája világszerte évről évre emelkedik. Jól ismert tény, hogy az e betegségben szenvedők kezelésében a veseátültetés hoszszabb túlélést biztosít, mint a múvesekezelés bármely formája [1-3]. Azonban a transzplantációt követően a várható túlélés így is rövidebb, mint a nem vesebeteg populáció esetében. Ennek fó oka a cardiovascularis betegségek gyakoribb előfordulása és a magasabb szív-ér rendszeri eredetû́ halálozás [4]. Ennek hátterében olyan tényezők állhatnak, mint a kövérség, az elsődleges vesebetegség (a saját vese primer betegsége), az átültetett szerv vártnál rosszabb funkciója, a lassan, halasztva meginduló graftmúködés (delayed graft function - DGF), a heveny kilökődés (akut rejectio - AR), a calcineurininhibitor- (CNI-) típusú gyógyszerekkel történő immunszuppresszív kezelés és az alkalmazott glükokortikoidok mellékhatásai. Ezenfelül oka lehet még a beültetett vese arteria renalisának stenosisa és idült allograft-károsodás (krónikus allograft-nephropathia - CAN). A fentiek miatt alapvető́n fontos a veseátültetésre váró betegek megfelelő szűrése és a mútétet követő értő gondozása [5].

Míg korábban a legnagyobb veszélyt a graft elvesztésére az akut kilökődés jelentette, napjainkban a beültetett vesék legnagyobb arányban krónikus allograft-neph- ropathia (CAN) miatt válnak múködésképtelenné. A beültetett vese idült károsodása multifaktoriális kórkép. Klinikailag a vesemúködés fokozatos beszúkülése, a salakanyagszint emelkedése, proteinuria, hypertensio jellemzi. Ez a kórkép, hasonlóan a cardiovascularis betegségekhez, több okra is visszavezethető. Az ismert etiológiai faktorokat immunológiai és nem immunológiai csoportra osztja az irodalom.

A renin-angiotenzin rendszerben közremúködő gének polimorfizmusainak szerepét mind a cardiovascularis szövődményekkel, mind a CAN-nal kapcsolatba hozták az utóbbi évek klinikai és kísérletes kutatásai. Kiterjedt vizsgálatokat végeztek mind kardiológiai, mind vesebeteg populációkon [6]. Egyes genotípusok kedvezőtlen prognosztikai faktorként szerepelnek a szív-ér rendszeri megbetegedés tekintetében, és sok szerző a CAN nem immunológiai rizikótényezőjeként is tekint rájuk.

Transzplantációt követően a cardiovascularis események kockázata ötvenszerese az átlagpopulációénak [4]. Klinikai vizsgálatok világítottak rá, hogy már 130/85 Hgmm-es értéknél magasabb vérnyomás esetén is gyakoribbá válik a jelentős rizikótényezőként elismert bal kamrai hypertrophia (LVH) és a hypertoniával összefüggésbe hozható ischaemiás szívbetegség (ISZB) kialakulása $[7,8]$. Az LVH kialakulásában a magas vérnyomás mellett olyan rizikótényezők szerepelnek, mint csökkent vesefunkció, vérszegénység és bizonyos genetikai tényezők [9]. A renalis parenchyma csökkent funkciója mind a folyadékterhelés fokozásán keresztül, mind a RAS fokozott aktiválódásával hozzájárul a szív megváltozott morfológiájához és így a csökkent funkciójához.

\section{Módszer}

Intézetünkben 1991 júniusában indult a cadavervese-átültetési program. A biztonság és az eredmények összehasonlíthatósága érdekében mind a donormútét, mind a beültetés során azonos elveket, standardizált technikát alkalmaztak a mútétet végző sebészek.

A jelen tudományos munka elvégzéséhez szükséges adatokat és vérmintákat az utógondozáson megjelent betegektől nyertük. A részletes tájékoztatást és a beleegyező nyilatkozat aláírását követően 72 beteget vontunk be a vizsgálatba 2009. január és 2011 áprilisa között. A vérvétel idején minden páciens betöltötte a 18 . 
életévét és beleegyezett adatai tudományos célú feldolgozásába.

Már a vizsgálat elején két jól elkülönített betegcsoportot alkottunk. Az egyik csoportban a részt vevő betegek normális vesefunkcióval rendelkeztek, és fontos kikötés volt, hogy esetükben az átültetés óta legalább 7 évnek kellett eltelnie. A másik betegcsoportban alapvető követelmény volt, hogy biopsziával igazolt krónikus allograftnephropathiájuk (CAN) legyen.

A vesemúködés ellenőrzése érdekében laborvizsgálat során elemeztük a szérumkreatinin koncentrációját, a glomerulusfiltrációs rátát (GFR), a vizeletfehérje koncentrációját és rögzítettük a vízhajtó kezelés tényét is.

Vizsgáltuk a betegek életkorát, nemét, testtömegét, testtömegindex-értékét (BMI) és haskörfogatát is. A vérnyomás vizsgálatakor standardizált körülmények között mértük a szisztolés és diasztolés értékeket, valamint a szívfrekvenciát is, és kiszámoltuk az artériás középnyomást (MAP). A betegek dokumentációjából kiemeltük az alkalmazott antihipertenzív szerek számát, típusát és dózisát. A kórtörténet felvételekor rákérdeztünk a dohányzási szokásokra, valamint a cukorbetegség esetleges meglétére. A laborvizsgálat során néztük az éhgyomri vércukorszintet, valamint elemeztük a szérumlipidszinteket.

A CAN etiológiai faktorait retrospektív módon dokumentáltuk és elemeztük.

A genomiális DNS-t perifériás vér fehérvérsejtjeiből izoláltuk FlexiGene ${ }^{\circledR}$ DNA Kit (Qiagen, Hilden, Németország) segítségével. A polimorfizmus-meghatározást polimeráz láncreakcióval (PCR) végeztük a Rigat és mtsai által leírt metódust követve [10].

Az ACE koncentrációját egy erre a célra kifejlesztett ELISA-módszerrel határoztuk meg (Human ACE ELISA development system, Cat. No. DY929), a gyártó elő́rásait kis módosításokkal követve.

A szérumminták ACE-aktivitását Beneteau és mtsai módszere alapján határoztuk meg, kis átdolgozást követően [11]. A minták ACE-aktivitását az alábbi képlet alapján számoltuk:

aktivitás $=(S / k) \times D$,

ahol $S$ az illesztés meredeksége $(1 / \mathrm{min}), k$ az 1 umol FAPGG hasítását követő optikaidenzitás-csökkenés, $D$ a szérum hígításának mértéke. Az ACE-aktivitás értékét unitban (U) adtuk meg úgy, hogy 1 U annak az enzimaktivitásnak a mértéke, ami 1 perc alatt 1 umol FAPGG-t hasít.

A veseátültetésen átesett betegek gondozása során előre meghatározott protokollt követünk intézetünkben. Ennek a gyakorlatnak része az is, hogy bizonyos időközönként szív-ultrahangvizsgálat történik a betegeknél, a még panaszt nem okozó elváltozások korai felderítésére és a már kialakult eltérések követésére, továbbá az alkalmazott kezelés sikerességének monitorozására.

A korábban említett 72 beteg közül azokat választottuk ki, akiknél az átültetést követően 4 hónapon belül, valamint egy évvel később és az utánkövetés során még legalább egy alkalommal készült részletesen leletezett és jól dokumentált echokardiográfiás vizsgálat.

Mindannyiuknál kétdimenziós és M-módú, valamint Doppler-felvételek készültek standard metszeti síkokban, a Debreceni Egyetem Kardiológiai Intézetének echokardiográfiás laboratóriumában.

Az elemzett UH-vizsgálatok alapján - az amerikai és az európai echokardiográfiás társaságok ajánlásának megfelelóen - számítottuk ki a bal kamrai izomtömeg indexét (LVMI) és így állapíthattuk meg a bal kamrai hypertrophia $(\mathrm{LVH})$ meglétét és annak súlyossági fokát [12].

A számításokhoz az alábbi, echokardiográfiás úton mért paramétereket használtuk: bal kamrai diasztolés átmérő (LVIDd), a szív hátsó falának diasztolés vastagsága (PWTd), valamint a septum diasztolés vastagsága (SWTd).

Ezeknek az adatoknak a felhasználásával az alábbi formula segítségével számoltuk ki a bal kamrai izomtömeget (LVM):

$\mathrm{LVM}=0,8 \times\left(1,04 \quad\left[\{\mathrm{LVIDd}+\mathrm{PWTd}+\mathrm{SWTd}\}^{3}-\right.\right.$ $\left\{\right.$ LVIDd $\left.\left.^{3}\right]\right)+0,6(\mathrm{~g})$.

A betegek testfelszínét (body surface area - BSA) a DuBois és DuBois formula segítségével számítottuk ki:

$\mathrm{BSA}=\left(\mathrm{W}^{0,425} \times \mathrm{H}^{0,725}\right) \times 0,007184\left(\mathrm{~m}^{2}\right)$, ahol a $W$ a testsúlyt (weight), a $H$ a testmagasságot (height) jelöli.

Ezt követően a bal kamrai tömegindexet (LVMI) a bal kamrai izomtömeg és a testfelszín hányadosaként kaptuk meg:

$$
\mathrm{LVMI}=\mathrm{LVM} / \mathrm{BSA}\left(\mathrm{g} / \mathrm{m}^{2}\right) \text {. }
$$

A bal kamrai hypertrophia súlyossági fokozatoknak megfelelő beosztásához az Amerikai Echokardiográfiás Társaság legutóbbi ajánlását használtuk. Ennek megfelelően mindkét nem esetében az alábbi kategóriákba soroltuk a betegeink adatait: normális, enyhén abnormális, közepesen abnormális és súlyosan abnormális.

A kapott számadatokat és értékeket átlag \pm szórás (SD, SEM) formában vagy százalékosan fejeztük ki és ábrázoltuk. A statisztikai vizsgálatokat a folyamatos változók esetében $t$-próbával, míg a kategorikus változók esetében $\chi^{2}$-teszttel végeztük.

A vesefunkció és a bal kamrai izomtömeg indexe (LVMI) és így a bal kamrai hypertrophia (LVH) mértéke közötti összefüggést lineárisregresszió-analízis segítségével vizsgáltuk.

Minden analízist a GraphPad Prism ${ }^{\circledR} 4.0$ (GraphPad Software Inc., San Diego, CA) szoftver segítségével végeztünk. A különbséget akkor tekintettük szignifikánsnak, ha a $p$-érték kisebb volt, mint 0,05.

\section{Eredmények}

\section{Krónikus allograft-nephropathia (CAN)}

Szövettani vizsgálat során 38 beteg esetében igazolták a CAN diagnózisát (CAN-csoport). A normális vesefunk- 
ciójú csoportba 34, olyan veseátültetésen átesett beteget választottunk, akik több mint 7 éve estek át a mútéten és a graft múködése normális salakanyagszintet biztosított nekik (NRF-csoport). Ebben a csoportban a kreatininszint átlagosan 95,68 $\pm 17,17 \mu \mathrm{mol} / 1$ volt.

A férfi:nő arány a CAN-csoportban 24:14 volt, míg az NRF-csoportban 23:11. A betegek átlagéletkora a transzplantációkor a CAN-csoportban 36,92 \pm 13,26 év volt, míg az NRF-csoportban 42,41 $\pm 11,59$ év. Az átültetés és a biopszia között a CAN-csoportban átlagosan 5,2 év telt el. A veseátültetés és a vizsgálatba történő bevonás között a kontrollcsoportban (NRF) hosszabb idő telt el - átlag 11,2 év -, mint a CAN-csoportban, ahol 8,3 év.

A betegek vesefunkciója a CAN-csoportban alatta maradt az NRF-csoporténak. A kontrollcsoportban a szérumkreatinin és a vizeletfehérje koncentrációja szignifikánsan alacsonyabb volt, míg a GFR értéke magasabb. A CAN-csoportban csaknem minden beteg (37 a 38ból) részesült diuretikus kezelésben. A kontrollcsoportban lévő betegek testtömegindexe (BMI) magasabb volt, csakúgy, mint a haskörfogatuk és a HDL-koleszterin-koncentrációjuk. A CAN-csoportban több beteg dohányzott.

Nem volt különbség a két csoport között a HLAegyezés, a citotoxikusantitest-titer mértékében, a későn induló graftfunkció (DGF) gyakoriságában, a hideg ischaemiás idő (CIT) átlagos hosszában, valamint a cytomegalovirus (CMV) státuszokat illetően sem.

A CAN-csoportban gyakrabban fordult elő heveny kilökődéses epizód (AR), és a donorok átlagéletkora is szignifikánsan magasabb volt. Minden vizsgálatba bevont beteg calcineurininhibitor- (CNI-) alapú immunszuppresszív kezelésben részesült. Az NRF-csoportban a tacrolimusalapú hármas kombináció volt a gyakoribb.

Az ACE-gén polimorfizmusának vizsgálata során azt találtuk, hogy az II genotípus előfordulási aránya nem különbözött a két vizsgált betegcsoportban. A CANcsoportban $13 \%$, míg az NRF-csoportban $12 \%$ volt az előfordulás gyakorisága $(p=0,83)$ (1. ábra).

A heterozigóta genotípus (ID) gyakrabban fordult elő a normális vesefunkciójú csoportban. A CAN-csoportban az ID előfordulása csak $55 \%$ volt, míg az NRF-csoportban $71 \%$, ami szignifikáns különbséget mutatott $(p=$ $0,02)$. A DD genotípus elemzésekor szintén szignifikáns különbséget találtunk. Ez a homozigótaváltozat lényegesen gyakrabban fordult elö a CAN-csoportban (32\%), mint azoknál a betegnél, akiknek a vesefunkciója normális volt $(18 \%, p=0,02)$.

Az ACE koncentrációjának meghatározása során azt tapasztaltuk, hogy az II homozigótáknál a legalacsonyabb az érték, míg a DD genotípusú betegnél a legmagasabb, és az eltérés statisztikailag is szignifikáns $(p=$ $0,02)$. Az ID heterozigótáknál mért ACE-koncentráció a két homozigótaérték közé esett.

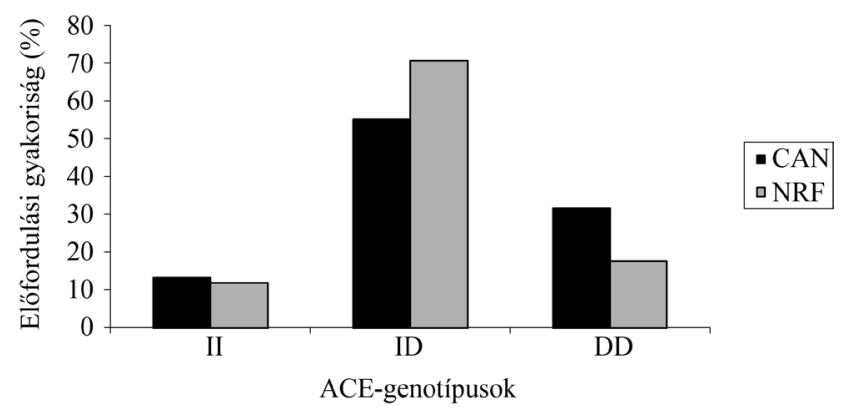

1. ábra Az ACE-genotípusok megoszlása a vizsgált betegcsoportokban
Az $y$ tengely az elófordulási gyakoriságot mutatja százalékos ér-
tékben. A fekete oszlopok a krónikus allograft-nephropathiás
(CAN) betegek, míg a szürke oszlopok a normális vesefunkciós
betegek (NRF) adatai. Az I az insertiós allélt, míg a D a deletiós
allélt jelöli. Az ID és a DD genotípusok esetében az eltérés szig-
nifikáns. A statisztikai elemzés során $\chi^{2}$-tesztet alkalmaztunk és
a $p<0,05$ értéket tekintettük szignifikánsnak

Vizsgáltuk a szérumban az ACE aktivitását is. A kapott eredmények jó összefüggést mutattak az expresszióval azoknál a betegeknél, akik nem részesültek ACEgátló kezelésben. A gén aktivitása az II genotípusú betegcsoportban volt a legalacsonyabb, ennél magasabb az ID heterozigótáknál, és a legmagasabb értéket a DD homozigóta csoportban mértük. Ez utóbbi csoportnál kapott érték szignifikánsan magasabb volt mindkét másik csoport értékeinél (ID vs. DD $p<0,01$, II vs. DD $p=$ $0,01)$.

Vizsgáltuk az ACE-gátló kezelés hatásosságát is. Azoknál a betegeknél, akik nem részesültek ACE-inhibitor kezelésben, a mért enzimaktivitás $30 \mathrm{U} / 1$ volt, míg az ilyen kezelésben részesülő betegeknél szignifikánsan alacsonyabb értéket mértünk ( $11 \mathrm{U} / 1, p<0,01)$. A kapott eredmények részletes elemzése során azoknál a be-

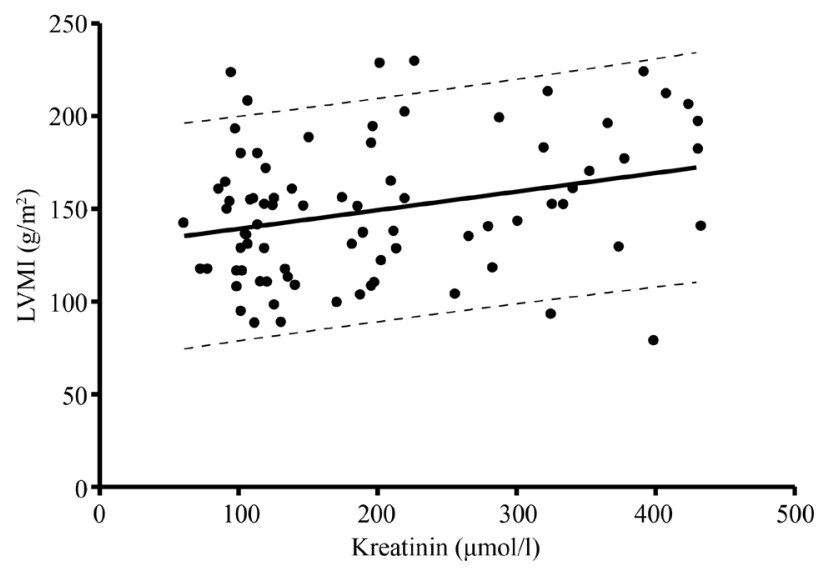

2. ábra

A bal kamrai tömegindex (LVMI) és a vesefunkció (kreatinin)
közötti összefüggés
A függőleges tengelyen ábrázoljuk a bal kamrai izomtömeg in-
dexét $\left(\mathrm{g} / \mathrm{m}^{2}\right)$, míg a vízszintes tengelyen a kreatininszint értékei
találhatóak $(\mu \mathrm{mol} / \mathrm{l})$. A pontok az egyes betegek adatait jelölik.
A folytonos vonal az átlagértékeket, míg a két szaggatott vonal
a $95 \%$-os konfidenciaintervallumot mutatja. A görbe meredek-
sége alapján számított korreláció szignifikáns $(p=0,0092)$ 
tegeknél, akik nem kaptak semmilyen ACE-inhibitort, váratlanul nagy variáció volt észlelhető a kapott eredmények tekintetében.

\section{Bal kamrai hypertrophia}

Miután meghatároztuk a betegek bal kamrai izomtömegindexét (LVMI) és a kapott értékeket a vesefunkcióval korreláltattuk, szignifikáns összefüggést találtunk (2. ábra).

Az ACE gén polimorfizmusa és a bal kamrai hypertrophia közötti kapcsolat vizsgálata során a bal kamrai tömegindex (LVMI) értéke alapján súlyossági fokozatokba soroltuk a betegeket. A bal kamrai hypertrophia (LVH) diagnózisának határértéke nóknél $95 \mathrm{~g} / \mathrm{m}^{2}$, míg férfiaknál $115 \mathrm{~g} / \mathrm{m}^{2}$ volt. Az első echokardiográfiás vizsgálat idejében az II genotípusú betegek 67\%-ánál, minden heterozigótánál (ID: 100\%), míg a DD homozigóták 86\%-ánál volt megállapítható az LVH valamely súlyossági fokozata. A második vizsgálat idején az II homozigóták 67\%-ánál, az ID heterozigóták 82\%-ánál, míg a DD genotípusúak 86\%-ánál. A harmadik szív-ultrahangvizsgálat során az II genotípusú betegek 67\%-ánál, az ID genotípusúak 76\%-ánál, míg a DD homozigóták 86\%-ában állt fenn az LVH diagnózisa.

A súlyos fokú LVH előfordulási gyakoriságát a három vizsgálati időpontban, a különböző genotípusok esetében a 3. ábra mutatja. Az első szív-ultrahangvizsgálat idején az II homozigótáknál egy esetben sem találtunk súlyos fokú LVH-t (II: 0\%), míg az ID genotípusúaknál 82\%-ban, a DD homozigótáknál pedig 57\%-ban volt fellelhető. A második echokardiográfia során súlyos fokú LVH-t az II genotípusú betegek egyharmadában (33\%), az ID genotípusúak 59\%-ában, míg a DD homozigótáknál 57\%-ban írtak le. Az utánkövetés során legutoljára elvégzett UH-vizsgálat alkalmával súlyos fokú LVH-t az II homozigóták 33\%-ánál, az ID heterozigóták 53\%ánál, míg a DD genotípusú betegek 71\%-ánál találtak.

Súlyos fokú bal kamrai hypertrophia (LVH)

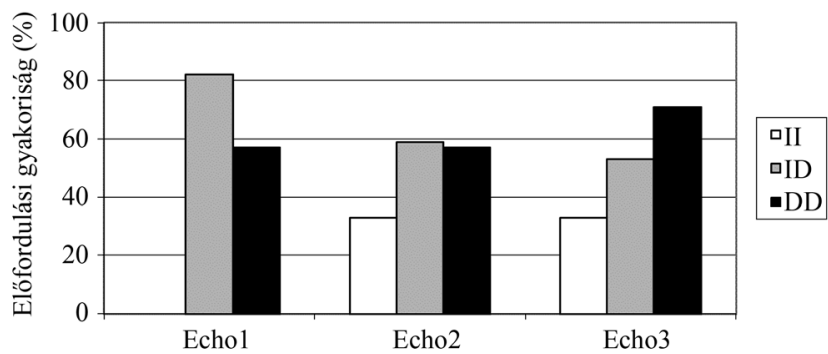

3. ábra $\quad$ Súlyos fokú bal kamrai hypertrophia (LVH) előfordulási gyakorisága a három vizsgálati időpontban a különböző genotípusoknak megfelelően

Az $y$ tengely jelöli az elófordulási gyakoriságot százalékos érték ben. A fehér oszlopok az II homozigóták, a szürke oszlopok a heterozigóták, míg a fekete oszlopok a DD-genotípusú betegek adatait jelölik

\section{Megbeszélés}

\section{Krónikus allograft-nephropathia}

A veseátültetés a krónikus vesebetegségben szenvedők számára olyan terápiás alternatíva, amely jelentősen jobb életminőség elérésével kecsegtet az egyéb terápiás lehetőségekkel (a mûvesekezelés egyéb formáival) összevetve. Az átlagpopuláció adataival összehasonlítva azonban a várható élettartam még így is rövidebb, és a beültetett vesék nagyobb részének károsodása is elkerülhetetlenül bekövetkezik bizonyos idő elteltével. A cardiovascularis betegségek és a fatális események kockázata az átlagosnál magasabb a transzplantált betegek körében. Ennek oka lehet a gyakran diagnosztizált hypertensio, a - részben gyógyszerek mellékhatásaként kialakuló - hypercholesterinaemia, a gyakoribb és súlyosabb érelmeszesedés, valamint a bal kamrai hypertrophia is. A graft elvesztésének leggyakoribb oka a krónikus allograft-károsodás. Ennek szövettani képe olyan degeneratív elváltozásokat mutat, amelyek kialakulásának hátterében a citokinrendszer és olyan effektorok aktiválódását feltételezzük, amelyek a kötő- és hegszövet kialakulásának kedveznek, kiszorítva így a múködőképes nefronokat. A magas vérnyomás és a célszervkárosodás etiológiájának tanulmányozásakor közös pontként azonosítható a renin-angiotenzin-aldoszteron rendszer (RAAS) és annak szabályozómechanizmusai. Olyan eltéréseket kerestünk, amelyek könnyen, gyorsan és lehetőleg noninvazívan azonosíthatók, továbbá segítenek megérteni e súlyos kórállapotok patológiáját, a terápia vagy a megelőzés eszközeinek ígéretével.

$\mathrm{Az}$ angiotenzinkonvertáló enzim I/D polimorfizmusát Rigat és mtsai írták le először 1990-ben, és nemcsak genetikai variánsként azonosították, hanem igazolták hatását a szérumban keringő enzim koncentrációjára is [10]. Közleményükben kiemelik, hogy az általuk vizsgált polimorfizmus felelős az ACE gén fenotípusos variánsainak 47\%-áért, így jelentős tényező az enzim mennyiségének szabályozásában.

$\mathrm{Az}$ ezt követő évtizedekben az I/D polimorfizmus szerepét sokan és sokféleképpen vizsgálták és vizsgálják ma is. Az ACE-gátlókkal végzett kezelés lassítja a vesebetegség progresszióját, és ezen megfigyelés hátterében állhat az imént említett genetikai változat is.

Artz és mtsai biopsziával igazolt CAN eseteit elemezték 2004-es közleményükben. A vizsgálat folyamán 72 beteg adatait elemezték, és azoknál a betegeknél, akik részesültek valamilyen RAS-gátlásban, szignifikánsan hosszabb túlélést találtak, mint azoknál, akik ilyen gyógyszeres kezelésben nem részesültek. Az átlagos grafttúlélés a gyógyszer adását követóen 6,3 év volt [13].

Munkánk tervezésekor kiemelten fontosnak tartottuk, hogy a két vizsgálati csoport a vizsgálni kívánt tulajdonságban élesen elkülönülő legyen. A CAN diagnózisánál a klinikai és laboratóriumi paraméterek mellett mindenképpen egy objektív vizsgálatra, a graftbiopszia szövettani eredményére kívántunk támaszkodni. Megbízható 
eredményekre csak úgy számíthattunk, ha megfelelően hosszú követési időszakot választunk, vagy - retrospektív vizsgálatnál - kellően hosszú idő telik el a beavatkozás (Tx) és a vizsgált esemény bekövetkezése (a CAN diagnózisának felállítása) és így az adatok elemzése között. Annak érdekében, hogy a multifaktoriális etiológiájú betegség vizsgálatánál minden kórok és az ezek közötti esetleges additív összefüggés is feltárásra kerüljön, megbízható dokumentációra és precíz elemzésre volt szükség. Ezzel nem mellékesen a korábbi vizsgálatok eredményeit is tesztelhettük és a saját betegcsoportjaink megfelelő elkülönülését is igazolhattuk.

Esetünkben a CAN diagnózisát minden betegnél szövettani vizsgálat eredményére alapoztuk. A normális vesefunkciójú csoportban minimum 7 év telt el a Tx-et követően. Vizsgáltuk a CAN minden ismert immunológiai és nem immunológiai etiológiai faktorát. Eredményeink azt mutatták, hogy a korábban, mások által már igazolt rizikótényezők közül a mi esetünkben is pozitív összefüggés volt kimutatható a donor életkora, valamint az akut kilökődés gyakorisága és a CAN kialakulása között. Eredményeink alapján az ACE I/D polimorfizmusa és a veseátültetést követően kialakuló CAN között egyértelmú, statisztikailag is igazolt összefüggés mutatható ki. A CAN-csoportban szignifikánsan nagyobb a DD genotípus előfordulási gyakorisága. A vizsgálatok során a genotípus és az enzim koncentrációja, valamint aktivitása között is összefüggést mutattunk ki.

\section{Bal kamrai hypertrophia}

A szív bal kamráját alkotó izomzat hypertrophiája nemcsak a pumpafunkció romlásával jár, hanem mint önálló rizikófaktor gyakrabban vezet potenciálisan fatális kimenetelû́ cardiovascularis események kialakulásához. A megnőtt tömegú izomzat oxigén- és tápanyagigénye fokozott, azonban a vérátáramlás ezzel arányosan csökken. Az izomzatban futó, subendocardialis erek az összehúzódás fázisában komprimálódnak, így nemcsak relatív, hanem abszolút ischaemia alakulhat ki. Ez a mechanizmus fokozza azoknak a betegeknek a szív-ér rendszeri megbetegedési rizikóját, akiknél ezt a funkcionális és morfológiai eltérést diagnosztizálják. 1990-ben publikálták a Framingham Heart Study eredményeit [14], amelyben külön kitérnek a bal kamrai izomtömeg prognosztikai jelentőségére.

A bal kamrai hypertrophia kezelése komplex és meghaladná e dolgozat kereteit, de az megemlítendő, hogy a gyógyszeres kezelés sarkalatos pontja a RAS-gátlók alkalmazása. Morath és mtsai 2009-ben közölt összefoglalójának célja az volt, hogy megvizsgálják a RAS-gátlás jelentőségét és alkalmazhatóságát veseátültetést követően [15]. Külön kiemelik e szerek antiproliferatív hatását és ennek tulajdonítják, hogy csökkentik a myocardialis infarctus, a stroke és a cardiovascularis mortalitás arányát. Véleményük szerint szintén az antiproliferatív effektusnak és a vérnyomás csökkentésének lehet szerepe abban is, hogy a vesebetegek esetében az ACE-gátló kezelés hatására csökken a proteinuria foka. Kiemelik azt is, hogy vesetranszplantált betegeknél RAS-blokád hatására csökkent a szív bal kamrai tömege és a bal kamrai hypertrophia mértéke.

A veseátültetésen átesett betegek cardiovascularis kockázata extrém magas az átlagpopulációhoz viszonyítva, és ebben kiemelkedően nagy szerep jut olyan rizikófaktoroknak, mint az LVH.

Minden közlemény szerzői egyetértenek abban, hogy a szív morfológiai és funkcionális eltérései szignifikánsan gyakoribbak a veseátültetett betegeken, mint az átlagpopulációban. Abban is széles körú a megegyezés, hogy a multifaktoriális etiológiájú LVH önálló rizikófaktor és a rendkívül gyakori CV-szövődmények nagy részéért felelőssé tehetô. Abban azonban nincs teljes megegyezés, hogy az LVH kialakulásában van-e szerepe a genetikai tényezőknek, illetve, ha van, akkor milyen mértékben. Szintén eltérőek az adatok abban az értelemben is, hogy a genetikai adottságok befolyásolják-e és ha igen, milyen irányba és mértékben az alkalmazott specifikus terápiát. Sok nyitott kérdés vár tisztázásra, és jól tervezett, a zavaró hatásoktól megszúrt, kellő számú betegen elvégzett vizsgálatokra van szükség ezek megválaszolására.

Munkánk során a betegeknél végzett egyes szív-ultrahangvizsgálatok között hosszabb idő telt el, így kiegyenlítődtek az egyéb etiológiai faktorok hatásai, és nem befolyásolta eredményeinket a korai morfológiai javulás, amelyet az átültetést követố első 1-2 évben írnak le. Eredményeink alapján egyértelmű összefüggés volt kimutatható a vesefunkció és a bal kamrai izomtömeg indexe (LVMI) között. A szív-ultrahangvizsgálatok eredményei pedig azt igazolták, hogy a DD genotípusú betegek esetén gyakoribb és a követési idő során növekvő tendenciát mutat a súlyos fokú LVH előfordulása.

\section{Következtetések}

A végstádiumú vesebetegségben szenvedők kezelésében a veseátültetés hosszabb túlélést biztosít, mint a vesepótló kezelések bármely formája. A transzplantációt követően azonban a várható túlélés még így is rövidebb valamelyest, mint a nem vesebeteg populáció esetében. Ennek fö oka a cardiovascularis betegségek gyakoribb előfordulása és a magasabb szív-ér rendszeri eredetû halálozás. Transzplantációt követően a cardiovascularis események kockázata többszöröse az átlagpopulációénak, noha jelentősen alacsonyabb, mint vesepótló kezelés mellett.

Míg korábban a legnagyobb veszélyt a graft elvesztésére az akut kilökődés jelentette, napjainkban a figyelem már a hosszú távú túlélésre terelődött. A beültetett vesék legnagyobb arányban krónikus allograft-nephropathia miatt válnak múködésképtelenné. Ez utóbbi kórállapotot klinikailag a vesemúköóés fokozatos beszúkülése, a salakanyagszint emelkedése, proteinuria, hypertensio jellemzi. A kórkép, hasonlóan a cardiovascularis betegségekhez, több okra is visszavezethető. Az ismert etiológiai 
faktorokat immunológiai és nem immunológiai csoportra osztja az irodalom.

A renin-angiotenzin rendszerben közremúködő gének polimorfizmusainak szerepét mind a cardiovascularis szövődményekkel, mind a CAN-nal kapcsolatba hozták az utóbbi évek klinikai és kísérletes kutatásai. Egyes genotípusok kedvezőtlen prognosztikai faktorként szerepelnek a szív-ér rendszeri megbetegedés tekintetében, és sok szerző a CAN nem immunológiai rizikótényezőjeként is tekint rájuk. Az eredmények azonban sokszor ellentmondásosak. Az eltérő beteganyagon, változó betegszámmal és különböző kiválasztási kritériumok alapján elvégzett vizsgálatok eredményei nem egybehangzóak, így nem alakulhatott ki egyértelmú állásfoglalás e gének, illetve polimorfizmusainak lehetséges szerepéről.

Munkánk során célul túztük magunk elé, hogy egy noninvazív vizsgálat során olyan pontosan mérhető paramétert találjunk, amellyel a beültetett vese hosszú távú túlélése egyértelmú összefüggést mutat. Célunk volt vizsgálni az ACE-gén I/D polimorfizmusának szerepét a graft hosszú távú túlélésében.

Vizsgáltuk az ACE-gén említett polimorfizmusának és a bal kamra hypertrophiájának összefüggéseit, azzal a céllal, hogy összefüggést mutassunk ki a genetikai módosulat és a betegek cardiovascularis rizikója között.

Összességében egy olyan jól definiálható, noninvazív módon meghatározható, fájdalommentesen, reprodukálható módon mérhető paramétert kerestünk, amelynek ismerete és befolyásolása kedvező hatással lehet a beültetett vese és/vagy a transzplantált beteg hosszú távú túlélésére, életminőségére.

Eredményeink alapján elmondható, hogy az ACE-gén I/D polimorfizmusa nagy jelentőséggel bír mind az átültetett vese, mind a recipiens hosszú távú túlélésében. Méréseink azt támasztották alá, hogy a D allél jelenléte, a DD genotípus fokozott rizikót jelent mind a krónikus allograft-károsodás kialakulásában, mind a súlyos fokú bal kamrai hypertrophia előfordulásának tekintetében.

Célkitűzésünknek megfelelően sikerült egy olyan noninvazív módon mérhető, reprodukálható vizsgálatot és jól dokumentálható tényezőt találnunk, amely összefüggést mutat a napjainkban vizsgált legnagyobb jelentőségü kórállapotokkal, amelyek a transzplantált betegek életét és vesefunkcióját veszélyeztetik.

Az ACE-gén I/D polimorfizmusának ismerete nemcsak arra ad lehetőséget, hogy a beteg és a graft túlélését megbecsüljük, hanem a speciálisan ható szerek alkalmazásával célzott terápiás beavatkozásra is lehetőségünk adódik. A korábban megkezdett és személyre szabottan alkalmazott RAS-gátló kezelés lehetőséget teremthet a vese krónikus károsodásának megelőzésére, a folyamat progressziójának lassítására és a cardiovascularis rizikó csökkentésével a beteg életminőségének javítására és túlélésének növelésére is.

A renin-angiotenzin-aldoszteron rendszer múködésének és szabályozási folyamatainak részletesebb megisme- rése és alaposabb vizsgálata a későbbiekben még további prognosztikai, diagnosztikai vagy akár terápiás lehetőségeket adhat a kezünkbe.

Anyagi támogatás: A közlemény megírása és a kapcsolódó kutatómunka anyagi támogatásban nem részesült.

Szerzői munkamegosztás: K. D. Á.: Adatgyűjtés, rendszerezés. †L. L.: Irodalmi adatok áttekintése, vonatkozó vizsgálatok rendszerezése. F. M.: Laboratóriumi vizsgálatok elvégzése, statisztikai elemzés. A. L.: Protokollok összefoglalása, kezelési terv felállítása. T. A.: A végleges munka megszövegezése, áttekintése, javítása. F. R.: A hipotézis kidolgozása, irodalmi adatok kigyújtése, rendszerezése, protokoll felállítása, a vizsgálat lefolytatása, minták begyújtése, tárolása, feldolgozása, adatok elemzése, kiértékelése, rendszerezése, a dolgozat megszövegezése. A cikk végleges változatát egy szerző kivételével (†L. L.) minden szerző elolvasta és jóváhagyta.

Érdekeltségek: A szerzőknek nincsenek érdekeltségeik.

\section{Köszönetnyilvánítás}

A szerzők köszönetet mondanak a Debreceni Egyetem, Sebészeti Inté zet Szervtranszplantációs Nem Önálló Tanszékének, valamint a Kardiológiai Klinika Klinikai Fiziológiai Tanszéke minden dolgozójának a segítőkész együttmúködésért.

\section{Irodalom}

[1] Port, F. K., Wolfe, R. A., Mauger, E. A.: Comparison of survival probabilities for dialysis patients vs. cadaveric renal transplant recipients. JAMA, 1993, 270(11), 1339-1343.

[2] Schnuelle, P., Lorenz, D., Trede, M., et al.: Impact of renal cadaveric transplantation on survival in end-stage renal failure: Evidence for reduced mortalitiy risk compared with hemodialysis during long-term follow-up. J. Am. Soc. Nephrol., 1998, 9(11), 2135-2141.

[3] Wolfe, R. A., Ashby, V. B., Milford, E. L., et al.: Comparison of mortality in all patients on dialysis, patients on dialysis awaiting transplantation, and recipients of a first cadaveric transplant. N. Engl. J. Med., 1999, 341(23), 1725-1730.

[4] Ojo, A. O.: Cardiovascular complications after renal transplantation and their prevention. Transplantation, 2006, 82(5), 603611.

[5] Szabó, R. P., Varga, I., Balla, J., et al.: Cardiovascular screening and management among kidney transplant candidates in Hungary. Transplant. Proc., 2015, 47(7), 2192-2195.

[6] Navis, G., van der Kleij, F. G., de Zeeuw, D., et al.: Angiotensinconverting enzyme gene I/D polymorphism and renal disease. J. Mol. Med., 1999, 77(11), 781-791.

[7] Toprak, A., Koc, M., Tezcan, H., et al.: Night-time blood pressure load is associated with higher left ventricular mass index in renal transplant recipients. J. Hum. Hypertens., 2003, 17(4), 239244.

[8] Montanaro, D., Gropuzzo, M., Tulissi, P., et al.: Effects of successful renal transplantation on left ventricular mass. Transplant. Proc., 2005, 37(6), 2485-2487.

[9] Bauml, M. A., Underwood, D. A.: Left ventricular hypertrophy: an overlooked cardiovascular risk factor. Cleve. Clin. J. Med., 2010, 77(6), 381-387. 
[10] Rigat, B., Hubert, C., Albenc-Gelas, F., et al.: An insertion/deletion polymorphism in the angiotensin I-converting enzyme gene accounting for half the variance of serum enzyme levels. J. Clin. Invest., 1990, 86(4), 1343-1346.

[11] Beneteau, B., Baudin, B., Morgant, G., et al:: Automated kinetic assay of angiotensin-converting enzyme in serum. Clin. Chem., 1986, 32(5), 884-886.

[12] Lang, R. M., Bierig, M., Devereux, R. B., et al.: Recommendations for Chamber Quantification: A report from the American Society of Echocardiography's Guidelines and Standards Committee and the Chamber Quantification Writing Group, developed in conjunction with the European Association of Echocardiography, a branch of the European Society of Cardiology. J. Am. Soc. Echocardiogr., 2005, 18(12), 1440-1463.

[13] Artz, M. A., Hilbrands, L. B., Borm, G., et al.: Blockade of the renin-angiotensin system increases graft survival in patients with chronic allograft nephropathy. Nephrol. Dial. Transplant., 2004, $19(11), 2852-2857$.

[14] Levy, D., Garrison, R. J., Savage, D. D., et al.: Prognostic inplications of echocardiographically determined left ventricular mass in the Framingham Heart Study. N. Engl. J. Med., 1990, 322(22), 1561-1566.

[15] Morath, C., Schmied, B., Mehrabi, A., et al.: Angiotensin-converting enzyme inhibitors and angiotensin II type 1 receptor blockers after renal transplantation. Clin. Transplant., 2009, 23(Suppl. 21), 33-36.
(Fedor Roland dr., Debrecen, Móricz Zs. krt. 22., 4032 e-mail: drfedorroland@gmail.com)

\title{
HIRDETMÉNY
}

\author{
A Magyar Pathologusok Társasága és a Magyar Onkológusok Társasága \\ által a 2015. évre meghirdetett
}

\section{„A tüdődaganatok modern klasszifikációja és célzott terápiás lehetőségei” címü}

\section{KROMPECHER ÖDÖN-pályázat nyertesei:}

\section{I. helyezést ért el:}

„Fritz Lickint” jeligével

II. helyezett:

„VI. György” jeligével

III. helyezett:

„Aneurysma” jeligével

IV. helyezett:

„Nana” jeligével

\section{V. helyezett:}

„Expecto patronum” jeligével
Galambosi Gréta, a DE ÁOK V. évfolyamos hallgatója

Urbán Dániel, a SZTE ÁOK V. évfolyamos hallgatója

Vörös Fanni, a SE ÁOK III. évfolyamos hallgatója

Barcsák Emese, a PTE ÁOK IV. évfolyamos hallgatója

Kelemen Ágnes, a SE ÁOK V. évfolyamos hallgatója

Budapest, 2016. március

\author{
Magyar Pathologusok Társasága \\ és \\ Magyar Onkológusok Társasága \\ vezetősége
}

